\title{
Governmentality and Statification Towards a Foucauldian Theory of the State
}

\author{
Hein Jessen, Mathias ; von Eggers, Nicolai
}

Document Version

Accepted author manuscript

Published in:

Theory, Culture \& Society

DOI:

10.1177/0263276419849099

Publication date:

2020

License

Unspecified

Citation for published version (APA):

Hein Jessen, M., \& von Eggers, N. (2020). Governmentality and Statification: Towards a Foucauldian Theory of the State. Theory, Culture \& Society, 37(1), 53-72. https://doi.org/10.1177/0263276419849099

Link to publication in CBS Research Portal

\section{General rights}

Copyright and moral rights for the publications made accessible in the public portal are retained by the authors and/or other copyright owners and it is a condition of accessing publications that users recognise and abide by the legal requirements associated with these rights.

Take down policy

If you believe that this document breaches copyright please contact us (research.lib@cbs.dk) providing details, and we will remove access to the work immediately and investigate your claim. 


\section{Governmentality and Statification: Towards a Foucauldian Theory of the State}

\section{Mathias Hein Jessen and Nicolai von Eggers}

Journal article (Accepted manuscript*)

\section{Please cite this article as:}

Hein Jessen, M., \& von Eggers, N. (२०२०). Governmentality and Statification: Towards a Foucauldian Theory of the State. Theory, Culture \& Society, 37(1), 53-72. https://doi.org/10.1177/0263276419849099

\section{DOl: https://doi.org/10.1177/0263276419849099}

Copyright (C) The Author(s) २०19. Reprinted by permission of SAGE Publications.

* This version of the article has been accepted for publication and undergone full peer review but has not been through the copyediting, typesetting, pagination and proofreading process, which may lead to differences between this version and the publisher's final version AKA Version of Record. 


\title{
Governmentality and Statification
}

\section{Towards a Foucauldian Theory of the State}

Mathias Hein Jessen \& Nicolai von Eggers

\begin{abstract}
This article contributes to governmentality studies and state theory by discussing how to understand the centrality and importance of the state from a governmentality perspective. It uses Giorgio Agamben's critique of Michel Foucault's governmentality approach as a point of departure for reinvestigating Foucault as a thinker of the state. It focuses on Foucault's notion of the state as a process of statification which emphasises the state as something constantly produced and reproduced by processes and practices of government, administration and acclamation. As a result of this, the state appears as a given entity which is necessary for the multiplicity of governmental technologies and practices in modern society to function. Only by reference to the state can governmental practices be effective and legitimized. Finally, the article conceptualizesthe centrality of the state through Foucault's (preliminary) notions of the state as a 'practico-reflexive prism' and a 'principle of intelligibility'.
\end{abstract}

Keywords: Michel Foucault; Giorgio Agamben; Governmentality; State; Sovereignty 
Is it not precisely those who talk of the state, of its history, development and claims, who elaborate on an entity through history and who develop the ontology of this thing that would be the state? What if the state were nothing more than a way of governing? What if the state were nothing more than a type of governmentality? (Foucault, 2009: 234)

The now infamous notion of 'governmentality' developed by Michel Foucault in the Collège de France lecture series Security, Territory, Population and The Birth of Biopolitics from 1978 and 1979 has for decades attracted enormous scholarly attention. Following Foucault's programmatic declarations to 'cut off the head of the king in political thought' and analyse power outside the 'discursive-juridical model', governmentality has primarily been used to investigate the multiplicity of power relations in concrete practices and technologies of government as well as to understand the de-centralising governmental rationalities of liberalism and neoliberalism. This is what subsequently has been dubbed 'governmentality studies' (Barry et al., 1996; Burchell et al., 1991; Dean, 2010; Rose, 1999; Rose and Miller, 1992). While this approach formed a needed alternative to the dominant understanding of governmental practices and power in liberal democracies with a focus on parliamentarism and rational, legitimate decision- and law-making, it in effect abandoned the state as a level of analysis in favour of concrete practices and technologies of government (Curtis, 1995; Dean and Villadsen, 2016: 2; Kelly, 2009: 61-62; Lemke, 2000). However, even though the state may not be a sovereign decision maker, a Hobbesian quasi-transcendent entity hovering above and directing the lives of humans, it still plays a dominant role in the forms of government that characterise modern 
liberal democracies. The question is then what role the state plays in the multiplicity of governmental practices that characterise modern life and how can we - from a perspective that keeps the vital insights of a governmentality approach - understand and make room for the state in our analysis of contemporary governmental practices?

In this article, we use Giorgio Agamben's critique of Foucault's governmentality-approach to reinvestigate Foucault and develop a Foucauldian theory of the state. By taking a closer look at Foucault's statements on the state and governmentality in the governmentality-lectures and then reconstructing Agamben's understanding of the relation between sovereignty and government as well as between being and acting, we use this to understand the role of the state within a governmentality framework. Through this we identify two key points in developing a Foucauldian analytics of the state: On the one hand the state as a process of statification (something which is constantly produced and reproduced through governmental practices which become 'statified' or which 'statify' themselves) and on the other hand the state as a 'practico-reflexive prism' or a 'principle of intelligibility' (something which brings a multiplicity of governmental practices into existence, and through which these practices are understood and appear as a unity or as emanating from a central place). The notions of prism and principle are, it must be underlined, only briefly mentioned by Foucault. However, we attempt to develop them because they signify, in contradistinction to dispositifs, assemblages or technologies, how governmental practices both constitute the state so it appears as a given thing and because these practices are given meaning through and seem to emanate from the state.

In recent years, Foucault has been revived as a thinker of the state (Biebricher, 2013; Biebricher and Vogelmann, 2012; Jessop, 2007, 2011; Lemke, 2007; Saar, 2011; Sawyer, 2015). However, this literature still emphasises how Foucault has deconstructed and denaturalized the state, depriving it of any essence and focuses on the state as an effect of governmental rationalities, 
strategies and discourses. This misses a potential analytical strength in Foucault's approach to the state, namely to explain and analyse how the state is constructed and constituted as a given thing or as a given object and how it continues to play a central and constitutive role precisely because it is constructed and constituted as such by all the governmental practices and technologies that refer to it. Even though Foucault developed the notion of governmentality in order to investigate government and power at the state level without starting with or taking for granted the 'universal of the state', his thinking opens up for an analysis of how and why the state continues to play such a central role as an imaginary, fictive or discursive object that links the multiplicity of governmental practices together and make them appear as a given entity.

Building on Foucault's not thoroughly examined and scattered comments on the state on the one hand as a process of statification (governmental practices increasingly understood and made intelligibly through the prism of the state) and on the other as a 'practico-reflexive prism', or a, 'principle of intelligibility', we argue that these notions can help understand how and why the state continues to play such a central and constitutive role precisely because only by reference to some central entity (the state) can governmental practices exist and appear as legitimate. Only by seeming to emanate from the state can governmental practices have a concrete effect. Throughout history, through the process of statification, the state has become the object and subject around which our political understanding is constructed and revolves. As a consequence, it is central for the multiplicity and networks of governmental practices to have reference to a central point, to an object of the state, as if it exists. The notion of prism is thus central, because - as a result of the role the state has achieved in the process of statification - it is through the prism of the state that governmental practices make sense and gain their legitimacy.

To Agamben, it is Foucault's "methodological decision to set aside the analysis of the juridical universals" (Agamben, 2011: 273) which hinders him in completing the genealogy of 
governmentality and the understanding of power in the West. With his analysis of the Christian conceptualization of the relation between the sovereignty (of God), the holy trinity and the angelic bureaucracy, which at the same time derives its force from and acclaims and thereby upholds and perpetuate the sovereign God, Agamben provides the tools for a rereading of the relation between state and government in Foucault's thinking. Much work has been done on the relation between Foucault and Agamben, but focus has primarily been on the early part of the Homo Sacer project and the notions of exception, sovereignty and biopolitics (Calarco and DeCaroli, 2007; Lemke, 2011; Ojakangas, 2007; Patton, 2007; Snoek, 2010). The latter part of the Homo Sacer project, revolving around government and governmentality and its relation to Foucault, has been explored to a much lesser extent (Dean, 2012a, 2012b, 2013).

This article is thus also a contribution to understanding the relation between Foucault and Agamben's respective understandings of governmentality. Whereas the existing literature has focused primarily on the notion of power, this article uses Agamben's critique to revisit and productively read Foucault's notions of governmentality and state. By highlighting Agamben's attempt to create a 'modal ontology' in The Use of Bodies (Agamben, 2015), the article shows that the indistinction or modality is a central ontological character in Agamben's work which underlines his intention to see state and government not as two levels where one has an temporal or functional prevalence over the other, but as a extremes in a continuum continually oscillating between each other. We then use these insights to re-read Foucault's thinking on state and governmentality and argue that focusing on the state on the one hand as a process of continual statification and on the other as a prism through which governmental practices evoke their legitimacy and efficacy is central to understanding the central and necessary role that the state plays in the workings of governmental practices and technologies today. 


\section{The State as Statification}

Foucault's interest in the state and governmentality begins in the middle of the 1970s, primarily in Discipline and Punish (1975), the first volume of The History of Sexuality, The Will to Knowledge (1976) and the lecture series Society Must Be Defended (1975-76). Here Foucault gradually moves from an analysis of micro-power (the prison and sexuality) towards a macro-perspective (the state and governmentality). Here, Foucault also introduces the notion of 'biopolitics' together with that of disciplinary power as ways of avoiding what he calls the dominant 'juridical-discursive' notion of power. Foucault is concerned with moving away from a juridical conception of power focused around sovereignty, law and command and towards an analysis of how power works and functions in concrete practices and how subjects and subjectivities are created (Foucault, 1982). The aim is to start not with the alleged centre of power, the king, the state or sovereignty and then from there deduce what power is. As Foucault expresses it in Society must be defended, in order to understand how power functions, "[w]e have to study power outside the model of Leviathan, outside the field delineated by juridical sovereignty and the institution of the State" (Foucault, 2003: 34). It is the same sentiment that he expresses in the famous statement from The Will to Knowledge: "In political thought and analysis, we still have not cut off the head of the king" (Foucault, 1998: 88-89). Here, Foucault starts his path towards an analysis of the state (what would become governmentality), an analysis which seeks to avoid the language of the state, the juridical-discursive notion of power with its focus on law, rights and sovereignty.

In the two following lecture series - Security, Territory, Population and The Birth of Biopolitics - Foucault is increasingly interested in the state and state power, but is very explicit about not developing a theory of the state or of assuming the state as a given entity. It is in a discussion about state-phobia in the fourth lecture of The Birth of Biopolitics that Foucault states: "I must do without a theory of the state, as one can and must forgo an indigestible meal" (Foucault, 2010: 76- 
77; Lemke, 2007). This does not mean, in any way, Foucault underlines, cancelling "the presence and the effect of state mechanisms", because for Foucault, he does "exactly the opposite of this" (Foucault, 2010: 77). Doing without a theory of the state does not mean that there are not power effects of that which we call the state. In the first lecture of The Birth of Biopolitics, Foucault clearly states that what he is interested in, as was the case in Security, Territory, Population, is "the government of men insofar as it appears as the exercise of political sovereignty." (Foucault, 2010: 2). Foucault, then, is explicitly concerned with the exercise of sovereign power, with its practical side. But, this does not mean that one should not acknowledge the crucial role of the state in the exercise of that power.

In fact, Foucault goes as far as to suggest that all his research hitherto, whether it concerned madness, sexuality or the prison, was concerned with the state. "[W]hat was involved in each case," Foucault says, "was always the identification of the gradual, piecemeal, but continuous takeover by the state of a number of practices, ways of doing things, and, if you like, governmentalities. The problem of bringing under state control, of 'statification' [étatisation] was the heart of the questions I have tried to address" (Foucault, 2010: 77). Foucault claims that in all the different analyses and investigations he had earlier done, the same logic or reason had been at the centre of his interests: The reason of government or governmental reason or what he will call governmentality. What he investigated there, the ways of understanding and producing knowledge of different practices, have all been governmental practices or ways of governing. And he asserts that he has always been interested in how these practices or processes of knowledge production and government(alities) were gradually taken over by the state, coming under state control and becoming 'statified'.

The history of governmentality is the history of how a number of governmental practices are understood through and via the same umbrella, the same prism, that is, the state (Foucault, 2009, p. 118). In this analysis, statification (étatisation) denotes the process whereby a number of 
governmental rationales and practices are bound together and articulated from a combined, unitary perspective in that which we call and understand as the state. Governmentality (as statification) can be categorized as a meta-reflexion on the existing (or already investigated) governmental rationales and their (possible) connection in the state (Foucault, 2009, p. 118).

If Foucault is so interested in the state and the role it plays in the development of governmental practices, how then should we understand his aversion against developing a theory of the state? ${ }^{2}$ When Foucault says that he must do without a theory of the state, that means "not starting off with an analysis of the nature, structure, and functions of the state in and for itself, if it means not starting from the state considered as a sort of political universal" (Foucault, 2010: 77). To Foucault it is important to stress that "the state does not have an essence. The state is not a universal nor in itself an autonomous source of power" (Foucault, 2010: 77). The state - or that which we normally call or investigate as the state - is "nothing else but the effect, the profile, the mobile shape of a perpetual statification (étatisation) or statifications [...] The state is nothing else but the mobile effect of a regime of multiple governmentalities" (Foucault, 2010: 77). The state is nothing in and for itself. Rather, it is a way or mode of being, a way or mode of governing, an object which although it does not exist is the unifying point of a number of discourses and (governmental) practices and governmentalities. The state plays a central role in the exercise of political power, because it is through the (imagined, fictive, discursive) prism of the state that government can be understood. It is this notion that we can better understand in Foucault by turning to Agamben's problematization of governmentality in The Kingdom and the Glory.

\section{Governmentality as Oikonomia}

Giorgio Agamben begins The Kingdom and the Glory with a direct acknowledgement of the influence from Foucault by stating that the study "locates itself in the wake of Michel Foucault's investigations 
into the genealogy of governmentality" while it at the same time "aims to understand the internal reasons why they failed to be completed" (Agamben, 2011). Agamben's Homo Sacer project was from the very beginning heavily influenced by Foucault as it, in the words of Agamben, "concerns precisely the hidden point of intersection between the juridico-institutional and the biopolitical models of power" (Agamben, 1998: 6). In The Kingdom and the Glory, this project "reaches a point that is in every sense decisive" (Agamben, 2011) through a direct engagement with the notion of governmentality, which is not present in the earlier Homo Sacer books. Agamben's critique of Foucault's analysis of governmentality is twofold. First, it is historical-temporal and moves "well beyond the chronological limits that Foucault assigned to his genealogy, to the early centuries of Christian theology" (Agamben, 2011, xi). Second, and more decisively, it takes aim at Foucault's lack of focus on the political universals: 'state' and 'sovereignty' (Agamben, 2011: 273; see also Dean, 2012a, 2013).

The subject of The Kingdom and the Glory is a reading of church-fathers from the second to the fifth centuries AD that focuses on how attempted to explain how God could at the same time be one (almighty and indivisible) and three (in the Holy Trinity of God, Christ and the Holy Spirit). They did this through the notion of an oikonomia, a government of the world. God is naturally one in being, in essence, but governs or administers the world, in the form of the trinity. From this, according to Agamben, emerges a distinction between theology and economy, between the being of God and his activity (Agamben, 2011: 5). What is solved through the conceptualization of the holy trinity as oikonomia, as government of the world, is that God can remain one, undivided and sovereign, while at the same time governing the world through others. This means that "the Trinity is not an articulation of the divine being, but of its praxis" (Agamben, 2011: 41). It is in this sense that the Trinitarian oikonomia constitutes "a privileged laboratory for the observation of the working and articulation" of what Agamben calls "the governmental machine" (Agamben, 2011). This 
'governmental machine' consists of two political paradigms. On the one hand a political theology concerning the one, the transcendental God, and which provides the foundation for classical political philosophy with its focus on indivisible sovereignty. On the other hand an economic theology concerning oikonomia; that is, practical-administrative government (Agamben, 2011, 1; see also Dean, 2013, 167). It is this distinction between the essence or being and the ways of being that according to Agamben lies at the heart of the Western conception of the political, and it is this "schizophrenia that the theological doctrine of oikonomia left as its legacy to Western culture" (Agamben, 2009b: 10). In Agamben's view the relevance of the Trinitarian oikonomia goes far beyond his own and Foucault's specific investigations. Instead, the distinction between sovereignty and government is constitutive of the entire tradition of Western political thinking, including that of Foucault - only Foucault shifts focus from the one side of the political machine (sovereignty), which he completely abandons in favour of a focus on its other constitutive element (government), thereby missing the constitutive relation between the two.

Agamben's argument is that political theology (sovereignty, state, politics) and economic theology (economy, administration, government) are not two separate spheres, where one has temporal or functional prevalence over the other. The two sides are inextricably linked and "functionally related" elements of the governmental machine (Agamben, 2011: 1; see also Bussolini, 2010: 97). Agamben's more substantial critique or correction of Foucault is that he focused too strongly on the one side of the governmental machine - government(ality), biopolitics, discipline and thereby overlooked what Agamben calls the 'zone of indistinction' between state and government, politics and economy. It is in this sense that Foucault, as Agamben states, "has come as close as he possibly can to the intuition of the bipolar character of the governmental machine, although the methodological decision to set aside the analysis of the juridical universals prevent him from articulating it fully." (Agamben, 2011: 273). By abandoning the notions of state and sovereignty 
in the analysis of power, Foucault could not complete the study of governmentality or fully comprehend the functioning of power in the West.

Understanding how sovereignty and government have a common ground and are in fact mutually constitutive represents a deeper philosophical and ontological problem that is central to Agamben's thinking and his attempt to develop what he calls a modal ontology. ${ }^{3}$ In his earlier work, Agamben was interested in the Aristotelian notion of potentiality, especially in his controversial reading of Aristotle intepreting potentiality as non-actualization, but rather impotentiality: the ability to not become something, to remain a mere potential that is never or not necessarily actualised (Agamben, 1999; Ugilt, 2014: 28). The point is, very simply put, that Agamben wants to avoid the ontological distinction between essence and action, between potentiality and actualization, but see them as parts of a continuum, a zone of indistinction (Ugilt, 2014: 31-32; see also Agamben, 1998: §3; Barkan, 2013: 6, n. 24). In The Use of Bodies, the last part of the Homo Sacer project, Agamben attempts to develop a modal ontology where he seeks to avoid the distinction between being and beings (or ways or modes of being) dominant in Western philosophy and metaphysics. Analysing a rather obscure correspondence between G. W. Leibniz and Bartholomew Des Bosses, he claims that the fundamental question of Western metaphysics, including that of conceptualising politics, "is the problem of how one can conceive of the unity of composite substances, in such a way that this or that body does not seem to be only an aggregate of monads but can be perceived as a substantial unity" (Agamben, 2015: 146). The problem is how to conceive something as both a substantial unity and as an aggregate of a number of ways of being. Agamben writes that "we are accustomed to think in a substantival mode, while mode has a constitutively adverbial nature, it expresses not 'what', but 'how' being is" (Agamben, 2015: 164) This means that in a modal ontology, "between being and modes the relationship is neither of identity nor of difference, because the mode is at once identical and different" (Agamben, 2015: 164). 
To Agamben, then, there is no ontological difference between being and action; there is no such thing as being independent of beings, modes of being or ways of being. There is no such thing as 'power', 'human being', 'man', 'state', 'sovereigny' independent of action and practice. To Agamben, the zone of indistinction is ontological, and in this sense, there is no ontological difference between state and government. This means that the 'schizophrenia', the division between a political theology and an economic theology, between being and ways of being, that the theological doctrine has left as its legacy to Western culture is symptomatic of a greater metaphysical problem. While Foucault criticized those who conceive of the state as an essence, Agamben essentially argues that Foucault himself moved too far into the other camp, claiming ontological primacy for the ways of being; that is, practices of government. This is this schizophrenia and deadlock that Agamben wants to get out of.

As we will argue, however, with regards to the relation between state and government, Foucault himself has nonetheless pointed towards a way out. Conceiving of the state not as an entity but as a process of statification, and furthermore conceptualizing the state as a practico-reflexive prism or a principle of intelligibility provides a possibility to think this relation and interrelation between being (state) and ways of being (government), something that is both a multiplicity of modes and practices of government and understood as a substantial unity.

\section{The State as Practice, Prism and Principle}

According to Foucault, the state begins to emerge at the end of the $16^{\text {th }}$ century as a part of a new economy of power. Here, the practice of political government becomes specific to the exercise of political power and the government of human beings, with its own logic and rationality independent of God's government of the world (Foucault, 2009: 234-35). Foucault traces this new art of government in the doctrine of reason of state (raison d'État) and police (the constitution of good 
order). Central to this new economy of power is that it is no longer, as it was to Machiavelli, the power and well-being of the individual ruler that is central (Foucault, 2009: 64-65; Thorup, 2010: 48-50), but to keep the state (l'État) in a good state (en état) (Foucault, 2009: 288). In this way, the state becomes an object of an emerging (political) science and government, an "object of knowledge (connaissance) and analysis" (Foucault, 2009: 247). However, what we are interested here is how the state also comes to appear as a given object that unites a number of governmental practices. In his analysis of governmentality, Foucault is interested in is how the state emerges as a solution to a problem rather than as a 'thing' or 'concept'. Here, 'the state' emerges as an attempt to find a solution to concrete problems regarding how to rule. The state emerges as a prism through which it is possible to see and govern an object that is emerging: the population. To Foucault, the "constitution of a knowledge (savoir) of government is absolutely inseparable from the constitution of knowledge of all the processes revolving around population in the wider sense of what we now call 'the economy"" (Foucault, 2009: 106). The population or the economy becomes the object of government for this emerging art of government, and it must respect the movements, interests and desires of the population in order to secure the order of the territory (what would become 'police') and to secure wealth and economic growth (political economy).

What Foucault is interested in here is "the moment this something, the state, really began to enter into reflected practice" (Foucault, 2009: 247). This amounts to what Thomas Lemke has termed Foucault's "nominalist account of the state that stresses the central importance of knowledge and political discourses in the constitution of the state" (Lemke, 2007: 43). It is the emergence of the state as a thing, as a unity, as an object that must be understood, it is, in short "the entrance of the state into the field of practice and thought that we should try to grasp" (Foucault, 2009: 247). For Foucault, the great institutions of the state, the state apparatuses, the army, taxation, the judicial system, already existed, but what was essential for the emergence of (that which we call) 
the state was "for the entry of all these elements into the field of an active, concerted, and reflected practice" (Foucault, 2009: 247). It is the state understood in this way that Foucault at various points in Security, Territory, Population tries to conceptualize, but never systematically develops. He calls it an 'object of knowledge', a "reflexive prism" or a "practico-reflexive prism" (Foucault, 2009: 276), a "strategic schema" or a "principle of intelligibility" (Foucault, 2009: 290) in order to try to grasp the thing that the different governmental practices are beginning to be centred around and concentrated on. He also terms it, with reference to Immanuel Kant, the "regulatory idea of governmental reason" - that is, an idea that structures understanding, but which can say nothing about its empirical (constitutive) existence - which is "a way of thinking the specific nature, connections and relations between already given elements and institutions." (Foucault, 2009: 286). It is from these scattered notions that we choose to highlight those of prism and principle because we believe that they illustrate how the state both comes to appear as a given thing, but also that it becomes something, a prism, through which a number of governmental practices become intelligible and are understood. The state becomes the principle or prism through which all these governmental practices take place and have meaning. In this sense, the state is a 'practico-reflexive prism' or a 'principle of intelligibility' through which a number of governmental practices are centred in a process of statification (étatisation) and which in turn gives meaning, legitimacy and efficacy to these practices.

Temporally, as well as ontologically, the governmental practices and technologies have primacy to Foucault. As Thomas Lemke has highlighted, the state becomes an integral part of governmental practices, as "an instrument and effect of these practices, not their foundation or counterpart." (Lemke, 2007: 56). However, by applying Agamben's critique of governmentality to Foucault, we can also see the state as a prism or principle, rather than as a simple instrument or effect. Instead, the state should be seen as a necessary principle for the existence and legitimacy of governmental practices. Only through the prism or principle of the state can these practices come to 
exist and have effects as state effects. So, while the state is an effect of practices, they come to appear as the effect of the state. The state comes to appear as the foundation and will behind these governmental practices, which is central for their functioning in the first place. Or, to apply Agamben's notion of a modal ontology or a zone of indistinction, neither the state nor the governmental practices have temporal or functional prevalence or primacy of the other, but are continually constituted in relation to each other. How, then, should we precisely understand the relation between the governmental practices and the unity or sovereignty of the state? In the following, we shall answer this question by discussing Agamben's analysis of the role of acclamation and glory.

\section{Acclamation and Glory}

On the face of it, The Kingdom and the Glory appears as a radicalization of the state as having no essence and being merely an effect of governmental practices in the statement that the "center of the governmental machine is empty" (Agamben, 2011). There is no essence, no essential being at the centre of the state, but its very 'essence' lies in the way it governs, in the administrative, governmental practices (Agamben, 2011: 38). The seat of power (the state or sovereignty) is an empty seat around which a number of administrative and governmental practices revolve. Agamben, however, highlights the importance of this empty centre for the workings of the governmental machine, especially in terms of 'glory' and 'acclamation', which he believes to be necessary for the functioning of sovereignty (Dean, 2012a, 2013: 150-52, see also 2017a, 2017b). This can be illustrated through his engagement with angels in chapter 6 of The Kingdom and the Glory, entitled 'Angelology and Bureaucracy'. Here, Agamben turns to angels, which play a crucial role in Thomas Aquinas' conception of God's government of the world. The question of angels takes up a large portion of the first part of Thomas' Summa Theologica, De gubernatione mundi (On the government of the world) where the angels are 
the ones who administer and govern the work of God (Agamben, 2011: 148-50). ${ }^{4}$ Generally speaking, there are two classes of angels: those who govern or administer the world and as such constitute the link between God and human beings, and those who assist God and who have a contemplative function (assistere means to 'stand before', 'being in the presence of' someone). This latter group of angels assist God through their acclamatory function, their constant singing of God's praise. It is this glory which, according to Agamben, "must cover with its splendor the unaccountable figure of divine inoperativity" (Agamben, 2011: 163). Only through constant acclamation can power sustain the tale of itself as being almighty and sovereign. Or rather, only by singing the praise of an almighty sovereign can the angels draw the power they need to perform their governmental function.

The consequence, as Agamben writes, "is that the real problem, the central mystery of politics is not sovereignty, but government; it is not God, but the angel; it is not the king, but ministry; it is not the law, but the police - that is to say, the governmental machine that they form and support" (Agamben, 2011: 276). On the face of it, this seems like a reiteration of the Foucauldian point of not looking at state, sovereignty and law, but at practices and technologies of government. However, the point is that they form and support the governmental machine, the oscillation between the two poles of state and government. It is not God who creates the angels, but rather the angelic bureaucracy, the governing class (angel, minister, police), that creates the sovereign by way of acts of acclamation. And God in turn serves a necessary function in sustaining the legitimacy and power of the bureaucracy and the practices of government.

Applying this to our topic, we can say that the state is a fiction. But for power relations and governmental practices to function it is a necessary fiction. It needs to exist as if it were an object, a point of reference for the governmental practices. The state consists of a number of administrative and governmental practices understood and conceived as being subordinate, dependent upon and emanating from a centre. And therefore, this centre is important and central for the functioning of 
governmental practices. Without recourse to this centre, the practices could not work and would have no effects or legitimacy. They need the reference to the centre, just as the angels need the reference to the sovereign God, in order to be able to govern. The schizophrenia inherited by Western culture between a political and an economic theology makes it seem like we need to either give ontological, logical or temporal primacy to either God (the state) or the angels (government), but to Agamben, this opposition is simply false. They are both part of a continuum, and the governmental machine functions as a constant oscillation between the two extremes. While the governmental practices sing the praise of the state, they in turn need the figure of the state in order to exist and function. To use Foucault's notions, the state is a practico-reflexive prism or a principle of intelligibility that gives meaning, sense, efficacy and legitimacy to the multiplicity of governmental practices, actions and technologies. Only through the prism of the state can governmental practices function. With this is mind, let us take a look at what a Foucauldian analytics of the state could look like.

\section{Towards a Foucauldian Theory of the State}

As Foucault himself acknowledged, 'governmentality' was never a fixed and ready-made concept, but rather a tentative and experimental approach to investigate government at the macro-level. It was, as Foucault himself put it, a "little experiment of method" (Foucault, 2009, p. 358). It was developed as a way to investigate the state, or government at the level of the state, without assuming the given existence and essence of the state, without starting from the 'universal' of the state. In fact, Foucault believed that it was possible to combine the analysis of micro-powers with that of the state (Foucault, 2009: 358). Even though the 'governmentality-studies' recognizes that Foucault developed the notion of governmentality to analyse both the macro- and micro-level of power (Burchell, 1991: 122; Gordon, 1991: 4; Rose, 1999: 5), the macro-level of the state - as well as the interrelation between micro and macro - is in effect abandoned in favour of a focus on the concrete practices and 
technologies of government, on political power 'beyond the state' (Rose and Miller, 1992). By focusing on the state as something that increasingly rules not through law and command, but through a network of institutions and organizations, the state becomes one actor in a multiplicity of relations and interactions between a number of actors and institutions. This approach consequently fails to appreciate the central and constitutive role the state plays in contemporary society. The recent attempts to revive Foucault as a thinker of the state (Biebricher, 2013; Biebricher and Vogelmann, 2012; Jessop, 2007, 2011; Kelly, 2009; Lemke, 2007; Saar, 2011) have focused on the state as an effect of rationalities, strategies and discourses, and have thereby brought us a long way in understanding the state from a governmentality-perspective.

What we argue is that what a Foucauldian analysis of the state as stratification and prism highlights is that what is important in modern societies is that even though the state is not a given object and does not have an essence, it still appears as if it does. As such it is important for a number of governmental practices that refer to it, invoke it and legitimize themselves in relation to it. The state as a thing or as a given object has concrete, real and practical effects because it is referred to, invoked, fought over and struggled against. Through struggles, practices and discourses, the state is constituted as an entity which has concrete effects. ${ }^{5}$ Concrete practices simultaneously produce, constitute and uphold the state as a thing. Just as the state continues to be the prism through which we view, understand and contest political power.

So even though the 'juridico-political' theory of sovereignty, state and law is, as Foucault writes, "by no means adequate to describe the manner in which power was and is exercised" (Foucault, 1998: 87-88), the juridical language of law, sovereignty and rights is still "the code according to which power presents itself and prescribes what we conceive of it" (Foucault, 1998: 8788). The juridical theory of sovereignty has as its goal "to establish the essential unity of power" (Foucault, 2003: 44) and it thus becomes the code in which (state) power is represented. The state, as 
Foucault underlines, is still "absolutely essential as the target to be attacked [...] as the privileged position to be occupied" (Foucault, 2009: 109). One element of a Foucauldian analysis of the state is thus to analyse in what ways the state is constructed and used as a point of reference in struggles either for or against the state. As Foucault states in the epigraph to this article, it is "precisely those who talk of the state, of its history, development and claims, who elaborate on an entity through history and who develop the ontology of this thing that would be the state" (Foucault, 2009: 234).

The state is however not only constituted through discourse, strategy and rationalities, but also through a number of practices. Even though we know that the state as such does not exist, we still need the reference to the state and state authority in almost every aspect of our everyday lives. We need the roads and infrastructure that tax payed to the state delivers, we need state certifications for teachers, doctors, lawyers, dentists, etc. If we want to open a bar, start a company or an association, we need approval (or at least not the explicit disapproval) of the state. In everyday practices, we need the head of the king to remain on, we act $a$ s if the state exists as a given thing which can grant things and which can guarantee a number of things, such as for instance security, law and order, etc. All these concrete practices function, in a way, as concrete, practical acclamations of the state. In our everyday practice, we accept that it is the state which is the guarantor in the last instance of the validity of a number of social processes. By doing so, we uphold, and thereby constitute and produce the state as if it were a given thing. Even though it may not exist, it very much has concrete practical effects. Even though, as the motto that guides and runs through Agamben's The Kingdom and the Glory, and which Foucault also uses in Security, Territory, Population, 'the king rules, but does not goven', the king exactly does not govern, he still rules. It is still the state that has the formal political power. Or, to put it differently, even if the state has no existence as such it is still needed to make power operational, to breathe life and legitimacy into governmental practices of whatever kind. 
As Timothy Mitchell has highlighted, the definition and constitution of the state depends on distinguishing it from society (and we could add, the economy) (Mitchell, 1991). The state, Mitchell writes, must be analysed as a 'structural effect', as the "powerful, metaphysical effect that make such structures appear to exist" as something given and autonomous that exists 'out-there' (Mitchell, 1991: 94). We can see the same thing continuing to happen today in discussions of the state losing its sovereignty in the face of the increasing power of transnational entities and multinational corporations, or in the face of a globalizing economy. On the one hand, such discussions uphold that there once was a sovereign, territorial nation-state and thereby essentialise the state, and on the other hand such a distinction between the political (state) and the economic or society hides the fact that the two are in practice inextricably intertwined and interrelated. But in doing so, such discussions and practices uphold the state as a given thing, as the possessor of sovereignty and the site of the political. Thereby, such discussions function as a form of acclamation, singing the praise of the state by invoking it as a given thing and thereby come to produce and constitute it as a given object. Because the state has acheived a privileged position in our political understanding and practice (through the process of statification), and because the state continues to be the object around which our political understanding is constructed, it is continually upheld as a given thing through all the practices and discourses that evoke it, praise it, hate it, try to avoid it or hail it as the saviour of political and economic uncertainties. The state in this sense functions exactly like a prism or a principle through which a number of practices make sense and are understood. And thereby, even though the state is a fiction, it is a result and effect of numerous practices, strategies and discourses, it continues to appear as if it is a given, existing thing, and it is by reference to this thing that the multiplicity of governmental, economic, societal practices make sense and understand themselves.

\section{Conclusion}


The point that Agamben's engagement with Foucault brings forth is that the central role of the state as a centre around which the different de-centralised governmental practices draw their efficacy, legitimacy and power, and which at the same time produce the state as a thing and entity. This reading of Foucault highlights the centrality of the state as what we have used Foucault himself to conceptualise as a prism, an object of knowledge and principle of intelligibility to the functioning of governmental practices. In this sense, we in a way use the Agambian reading strategy of entwicklungsfähigkeit on Agamben and Foucault. Agamben takes the term from Ludwig Feuerbach and uses it to signify when the text under analysis "has reached a point of undecidability where it becomes impossible to distinguish between the author and the interpreter" (Agamben, 2009b: 13). By this we mean that we have perhaps taken Foucault to the limit, or perhaps beyond, of his own thinking. However, by highlighting these elements which are only scattered comments in Foucault's lectures, we believe there are elements in his thinking that open up for understanding the central role of the state from a governmentality perspective.

This entails viewing the state not as a given thing, but a continual process of formation, a process of statification, whereby a number of governmental practices are brought together and understood under the same prism or principle. The governmental practices must refer to a central point, must seem to emanate from a central place: the state. The state is an imaginary or constructed object that performs an important function: It is continually produced and reproduced by those engaged in a variety of governmental practices as the place wherefrom power emanates and is situated. Only through the recognition of the state as sovereign can it come to exist as such. It is through the constant invocations of a central power that the state can exist as an entity and unity. Only through the references to this central place can the governmental practices exist and be legitimized. Only by seeming to emanate from a central place can governmental practices have a concrete effect. Only by the reference to the entity of the state can there be something like state effects. These are the 
processes that can be analysed by conceiving of the state as a constant process of statification whereby governmental practices begin to revolve around, refer to and draw their legitimacy of what is constituted as the state. In this way, the state can be understood as a prism or principle through which the multiplicity of governmental practices are not seen as a mere multiplicity but are connected and drawing their power from a central point: the state.

\section{References}

Agamben, Giorgio (1998) Homo Sacer - Sovereign Power and Bare Life. Homo Sacer I Stanford: Stanford University Press.

Agamben, Giorgio (1999) Potentialities: Collected Essays in Philosophy. Stanford: Stanford University Press.

Agamben, Giorgio (2009a) The Signature of All Things: On Method. Cambridge, MA: Zone Books. Agamben, Giorgio (2009b) 'What Is an Apparatus?’ And Other Essays. Stanford: Stanford University Press.

Agamben, Giorgio (2011) The Kingdom and the Glory: For a Theological Genealogy of Economy and Government. Homo Sacer II, 2. Stanford: Stanford University Press.

Agamben, Giorgio (2015) The Use of Bodies. Adam Kotsko (tr.). Homo sacer IV, 2. Stanford: Stanford University Press.

Barkan, Joshua (2013) Corporate Sovereignty: Law and Government under Capitalism. Minneapolis: University of Minnesota Press.

Barry, Andrew, Osborne, Thomas and Rose, Nikolas (eds) (1996) Foucault and Political Reason: Liberalism, Neo-Liberalism, and Rationalities of Government. Chicago: University of Chicago Press.

Biebricher, Thomas (2013) Critical Theories of the State: Governmentality and the StrategicRelational Approach. Constellations 20(3): 388-405. DOI: 10.1111/1467-8675.12045.

Biebricher, Thomas and Vogelmann, Frieder (2012) Governmentality and State Theory: Reinventing the Reinvented Wheel? Theory \& Event 15(3).

Burchell, Graham (1991) Peculiar interests: civil society and governing 'the system of natural liberty'. In: Graham Burchell, Colin Gordon and Peter Miller (eds) The Foucault Effect: Studies in Governmentality. Chicago: Chicago University Press, pp. 119-150. 
Burchell, Graham, Gordon, Colin and Miller, Peter (eds) (1991) The Foucault Effect: Studies in Governmentality. Chicago: University of Chicago Press.

Calarco, Matthew and DeCaroli, Steven (eds) (2007) Giorgio Agamben: Sovereignty and Life. Stanford: Stanford University Press.

Curtis, Bruce (1995) Taking the State Back Out: Rose and Miller on Political Power. The British Journal of Sociology 46(4): 575. DOI: 10.2307/591572.

Dean, Mitchell (2010) Governmentality: Power and Rule in Modern Society. 2nd ed. London; Thousand Oaks, California: SAGE.

Dean, Mitchell (2012a) Governmentality Meets Theology: 'The King Reigns, but He Does Not Govern'. Theory, Culture \& Society 29(3): 145-158. DOI: 10.1177/0263276412438599.

Dean, Mitchell (2012b) The signature of power. Journal of Political Power 5(1): 101-117. DOI: 10.1080/2158379X.2012.659864.

Dean, Mitchell (2013) The Signature of Power: Sovereignty, Governmentality and Biopolitics. Los Angeles; London: SAGE.

Dean, Mitchell (2017a) Political acclamation, social media and the public mood. European Journal of Social Theory 20(3): 417-434. DOI: 10.1177/1368431016645589.

Dean, Mitchell (2017b) Three Forms of Democratic Political Acclamation. Telos 2017(179): 9-32. DOI: $10.3817 / 0617179009$.

Dean, Mitchell and Villadsen, Kaspar (2016) State Phobia and Civil Society: The Political Legacy of Michel Foucault. Stanford: Stanford University Press.

Flohr, Mikkel (2016) Regicide and Resistance: Foucault's Reconceptualization of Power.

Distinktion: Journal of Social Theory 17(1): 38-56. DOI:

10.1080/1600910X.2016.1145590.

Foucault, Michel (1982) The Subject and Power. Critical Inquiry 8(4): 777-795.

Foucault, Michel (1998) The Will to Knowledge: The History of Sexuality, Vol. 1. The History of Sexuality vol. 1. London: Penguin Books.

Foucault, Michel (2003) Society Must Be Defended: Lectures at the Collège de France, 1975-76. New York: Picador.

Foucault, Michel (2009) Security, Territory, Population: Lectures at the Collège de France, 197778. Basingstoke: Palgrave Macmillan.

Foucault, Michel (2010) The Birth of Biopolitics: Lectures at the Collège de France, 1978 - 79. Basingstoke: Palgrave Macmillan. 
Gordon, Colin (1991) Governmental rationality: an introduction. In: Graham Burchell, Colin Gordon and Peter Miller (eds) The Foucault Effect: Studies in Governmentality. Chicago: University of Chicago Press, pp. 1-51.

Hansen, Magnus Paulsen (2016) Non-normative critique: Foucault and pragmatic sociology as tactical re-politicization. European Journal of Social Theory 19(1): 127-145. DOI: $10.1177 / 1368431014562705$.

Jessop, Bob (1990) State Theory: Putting the Capitalist State in Its Place. Cambridge: Polity Press. Jessop, Bob (2007) From micro-powers to governmentality: Foucault's work on statehood, state formation, statecraft and state power. Political Geography 26(1): 34-40. DOI: 10.1016/j.polgeo.2006.08.002.

Jessop, Bob (2011) Constituting Another Foucault Effect: Foucault on States and Statecraft. In: Bröckling, Ulrich, Krasmann, Susanne and Lemke, Thomas (eds) Governmentality: Current Issues and Future Challenges. New York: Routledge.

Kelly, Mark G.E. (2009) The Political Philosophy of Michel Foucault. New York: Routledge.

Lemke, Thomas (2000) Neoliberalismus, Staat und Selbsttechnologien. Ein kritischer Überblick über die governmentality studies. Politische Vierteljahresschrift 41(1): 31-47. DOI: 10.1007/s11615-000-0003-8.

Lemke, Thomas (2007) An Indigestible Meal? Foucault, Governmentality and State Theory. Distinktion: Journal of Social Theory 8(2): 43-64. DOI: 10.1080/1600910X.2007.9672946. Lemke, Thomas (2011) Biopolitics: An Advanced Introduction. New York: New York University Press.

Mitchell, Timothy (1991) The Limits of the State: Beyond Statist Approaches and their Critics. American Political Science Review 85(1): 77-96. DOI: 10.1017/S0003055400271451.

Ojakangas, Mika (2007) Impossible Dialogue on Bio-power: Agamben and Foucault. Foucault Studies (2): 5. DOI: 10.22439/fs.v0i2.856.

Patton, Paul (2007) Agamben and Foucault on biopower and biopolitics. In: Calarco, Matthew and DeCaroli, Steven (eds) Giorgio Agamben: Sovereignty and Life. Stanford: Stanford University Press, pp. 203--218.

Poulantzas, Nicos (2014) State, Power, Socialism. Radical thinkers. London; New York: Verso. Rose, Nikolas (1999) Powers of Freedom: Reframing Political Thought. Cambridge: Cambridge University Press. 
Rose, Nikolas and Miller, Peter (1992) Political Power beyond the State: Problematics of

Government. The British Journal of Sociology 43(2): 173-205. DOI: 10.2307/591464.

Saar, Martin (2011) Relocating the Modern State: Governmentality and the History of Political

Ideas. In: Bröckling, Ulrich, Krasmann, Susanne and Lemke, Thomas (eds)

Governmentality: Current Issues and Future Challenges. New York: Routledge, pp. 34-55.

Sawyer Stephen, W. (2015) Foucault and the state. The Tocqueville Review/La revue Tocqueville 36(1): 135-164.

Senellart, Michel (1995) Les arts de gouverner: Du regimen médiéval au concept de gouvernement. Paris: Seuil.

Snoek, Anke (2010) Agamben's Foucault: an overview. Foucault studies (10): 44-67.

Thorup, Mikkel (2010) An Intellectual History of Terror: War, Violence and the State. London;

New York: Routledge.

Ugilt, Rasmus (2014) Giorgio Agamben: Political Philosophy. Tirril Hall, Tirril, Penrith:

Humanities-Ebooks.

\section{Notes}

\footnotetext{
${ }^{1}$ Foucault has some similar formulations in other works. In Subject and Power, he states that "[i]t is certain that in contemporary societies the state is not simply one of the forms or specific situations of the exercise of power - even if it is the most important - but that in a certain way all other forms of power must refer to it. [...] one could say that power relations have been progressively governmentalized, that is to say, elaborated, rationalized, and centralized in the form of, or under the auspices of, state institutions." (Foucault, 1982: 793). And in The Will to Knowledge, that "the state relies on the institutional integration of power relationships." (Foucault, 1998: 96; see also Jessop, 2011).

${ }^{2}$ It is important to underline that Foucault's treatment of the state (and his rejection of developing a state theory) was very much a critical engagement with existing conceptions of the state in his own time. He rejected outright the antistatism and 'state-phobia' of both the Marxist-Leninist notion of 'the withering away of the state' as well as in the fantasies of (neo)liberals (Dean and Villadsen, 2016: 15-18; Foucault, 2010). Foucault's thinking of the state is also a reflection on Marxist debates on the state at the time, most importantly the theories of the state found in the writings of Louis Althusser and Nicos Poulantzas. For Foucault's relation to Poulantzas and strategic-relational state thinking see (Biebricher, 2013; Jessop, 1990: 220-247, 2011; Poulantzas, 2014: 35-46).

${ }^{3}$ This is why Dean's (Dean, 2012b, 2013) notion of a 'signature' of power which refers to a "set of oppositions" like 'power to', 'power over, power as capacity, power as right "that in turn can become unities in relation to other opportunities" and that power, therefore "is marked by this recurrent bipolarity" (Dean, 2013: 12) is, as he himself acknowledges, "far more limited" than how Agamben uses it (Dean, 2013). To Agamben, the signature is an archeological-methodological term, which "in a sign or concept marks and exceeds such a sign or concept referring it back to a determinate interpretation or field [...]. Signatures move and displace concepts and signs from one field to another [...] without redefining them semantically." (Agamben, 2009a, 2011: 4). Thereby, it becomes a central methodological term to identify and trace genealogically the movement and displacement of the notion of government from the theological to the political and economic fields (and vice versa).

${ }^{4}$ This example is a good point of illustration of Agamben's use of the signature and one that illustrates his critique of Foucault and Foucauldians. To Agamben, the archeological-methodological notion of 'signature' is important because it makes it possible to trace the genealogy of government in for instance theological texts. In the example of Thomas Aquinas here, that the most central reflections on government is to be found in the reflections on God's government of the world, and not in the sections on the worldly prince's government, as he claims Michel Senellart had done in his Les arts de gourverner (Agamben, 2011: 112-13; Senellart, 1995).

${ }^{5}$ This seems very much to be in line with Foucault's focus on the (constitutive) relation between power, struggle, critique and resistance (Foucault, 1982: 794, 1998: 95; see also Flohr, 2016; Hansen, 2016).
} 